\title{
Anti-inflammatory and angiogenic effects of exercise training in cardiac muscle of diabetic mice
}

This article was published in the following Dove Press journal:

Diabetes, Metabolic Syndrome and Obesity: Targets and Therapy

\author{
Tom L Broderick' \\ Jacqueline M Sennott ${ }^{2}$ \\ Jolanta Gutkowska ${ }^{3}$ \\ Marek Jankowski ${ }^{3}$ \\ 'Laboratory of Diabetes and Exercise \\ Metabolism, Department of Physiology, \\ College of Graduate Studies, Midwestern \\ University, Glendale, AZ, USA; \\ ${ }^{2}$ Department of Cardiology, Medical \\ Education H23, Saint-Joseph Mercy \\ Health System, Pontiac, MI, USA; \\ ${ }^{3}$ Cardiovascular Biochemistry \\ Laboratory, CRCHUM (7-134), \\ Department of Medicine, University of \\ Montreal, Montreal, Quebec, Canada
}

Background: Improved glycemic control and cardiovascular function are major benefits of regular exercise training (ET) in type 2 diabetes. Recent work has demonstrated that ET improves cardiac and vascular functions independent of obesity, inflammation, and glucose control in the diabetic $\mathrm{db} / \mathrm{db}$ mouse. In this study, we determined whether ET can overcome the effects of elevated inflammatory cytokines and hyperglycemia on markers of cardiac angiogenesis and inflammation in the diabetic mouse.

Methods: Male diabetic $\mathrm{db} / \mathrm{db}$ mice were assigned to a sedentary and exercise-trained group. Sedentary lean control littermates were used as controls. ET was performed at moderate intensity on a treadmill 5 days a week for a period of 8 weeks. After ET, blood was collected for assay of glucose, hemoglobin ( $\mathrm{HB}$ and $\mathrm{HB}_{1 \mathrm{AC}}$ ), C-reactive protein (CRP), and IL-6. Markers of inflammation and insulin resistance (IL-6, IL-1 $\beta$, and tumor necrosis factor-alpha $[\mathrm{TNF}-\alpha]$ ) and angiogenesis (endothelial nitric oxide synthase [eNOS], vascular endothelial growth factor-A [VEGF-A], and hypoxia-inducible factor-1 $\alpha$ [HIF-1 $\alpha]$ ) were measured in hearts.

Results: Diabetic $\mathrm{db} / \mathrm{db}$ mice remained obese and hyperglycemic after ET. Percent total HB and $\mathrm{HB}_{1 \mathrm{AC}}$ were significantly higher in $\mathrm{ET} \mathrm{db} / \mathrm{db}$ mice compared to sedentary $\mathrm{db} / \mathrm{db}$ mice, indicating further deterioration of glucose control with ET. Plasma levels of CRP and IL-6 were higher in sedentary $\mathrm{db} / \mathrm{db}$ mice compared to control mice and were unaffected by ET. However, in the presence of hyperglycemia and elevated plasma cytokines, protein expression of eNOS, mRNA expression of VEGF-A, and HIF- $1 \alpha$ was increased in $\mathrm{db} / \mathrm{db}$ hearts after ET. On the other hand, protein expression of TNF- $\alpha$ and mRNA expression IL- 6 and IL-1 $\beta$ was significantly decreased by ET in hearts of $\mathrm{db} / \mathrm{db}$ mice.

Conclusion: Our results indicate that ET improves cardiac markers of angiogenesis, insulin resistance, and endothelial dysfunction in the $\mathrm{db} / \mathrm{db}$ mouse. This was observed independently of obesity, hyperglycemia, and the systemic inflammatory state.

Keywords: exercise, db/db, glycated hemoglobin, angiogenesis, inflammation

\section{Introduction}

It is well established that a sedentary lifestyle is a major risk factor for metabolic and cardiovascular diseases. ${ }^{1}$ Physical inactivity is associated with an increased prevalence of obesity, prediabetes, and type 2 diabetes mellitus (T2DM). ${ }^{2}$ Patients with these metabolic disorders are at increased risk of developing coronary artery disease (CAD), stroke, and peripheral artery disease. ${ }^{3}$ Decreasing the incidence of these adverse cardiovascular outcomes accompanying these disorders can be accomplished by effective nonpharmacological intervention in the form of regular physical activity. Exercise training (ET) performed on a regular basis decreases the
Correspondence: Tom L Broderick Laboratory of Diabetes and Exercise Metabolism, Department of Physiology, College of Graduate Studies, Midwestern University, 19555 North $59^{\text {th }}$ Avenue, Glendale, AZ 85308, USA

Tel +I 6235723664

$\mathrm{Fax}+$ I 6235723673

Email tbrode@midwestern.edu 
risk of $\mathrm{CAD}$ and slows the progression of endothelial dysfunction, resulting in improved blood flow and organ perfusion. $^{4-7}$

The benefits of ET on vascular function in diabetes are generally attributed to an improvement in glucose control, plasma lipids, and insulin sensitivity. ${ }^{4,6,8-10}$ Vascular function is also improved as a result of angiogenesis, resulting in capillarization and improved blood flow in tissues. ${ }^{11}$ In the streptozotocin (STZ) model of T1DM, impaired expression of the angiogenic marker vascular endothelial growth factor A (VEGF) in skeletal muscle is improved with ET. ${ }^{12-15}$ Furthermore, ET may improve vascular function by decreasing local expression of inflammatory cytokines, ${ }^{16}$ which are known to correlate with insulin resistance and endothelial dysfunction in T2DM. ${ }^{17-21}$ Recent studies indicate that chronic ET is beneficial on vascular function in the $\mathrm{db} / \mathrm{db}$ mouse model of T2DM. ${ }^{8,22,23}$ Stimulating angiogenesis and decreasing the expression of cytokines represent an important adaptation to ET as improved blood flow promotes the delivery of insulin for the disposal of glucose. However, the effects of ET on expression of inflammatory cytokines linked to vascular dysfunction and insulin resistance, and markers of angiogenesis in cardiac tissue of $\mathrm{db} / \mathrm{db}$ mice have yet to be addressed.

In this study, we selected the $\mathrm{db} / \mathrm{db}$ mouse to investigate the role of ET on the expression of cardiac cytokines and markers of angiogenesis. The $\mathrm{db} / \mathrm{db}$ mouse is characterized by an obese phenotype and exhibits many of the metabolic aberrations seen in human T2DM, including hyperglycemia and inflammatory activation by plasma and tissue cytokines. Levels of C-reactive protein (CRP), tumor necrosis factor-alpha (TNF- $\alpha)$, and interleukins are elevated in plasma of $\mathrm{db} / \mathrm{db}$ mice. ${ }^{23}$ Another feature of this model is that obesity, insulin resistance, and inflammatory state are not dramatically improved following ET, whereas benefits on vascular function are reported. ${ }^{8,22-28}$ Therefore, in this study, the effects of moderate-intensity ET on tissue inflammatory cytokines linked to vascular dysfunction and insulin resistance and markers for angiogenesis in hearts of $\mathrm{db} / \mathrm{db}$ mice were determined.

\section{Methods}

\section{Mouse model of diabetes}

Four-week-old diabetic $\mathrm{db} / \mathrm{db}$ mice (Jackson Laboratories, Bar Harbor, ME, USA) were used in this study. The $\mathrm{db} / \mathrm{db}$ mouse is characterized by two mutant copies of the leptin receptor gene $\left(\mathrm{C} 57 \mathrm{BL} / \mathrm{KsJ}-\mathrm{lept} \mathrm{db}^{\mathrm{db}}-\mathrm{lept}^{\mathrm{db}}\right)$ and was selected because of its close resemblance to the human T2DM condition. $^{29}$ Many of the metabolic perturbations associated with T2DM are displayed by this model, including a gradual onset, an obese phenotype, hyperglycemia, hyperinsulinemia, systemic inflammation, and left ventricular dysfunction. The lean littermates, which possess one mutant and one normal copy of the leptin $(\mathrm{db} /+)$ gene, served as controls. All mice used in this study were cared in accordance with the recommendations in The Guide for the Care and Use of Laboratory Animals, National Institute of Health, Publ. No. 85-23, 1986. The Institutional Animal Care and Use Committee of Midwestern University approved this study.

\section{ET protocol}

After a 2-week period of acclimation, $\mathrm{db} / \mathrm{db}$ mice were randomly assigned to either a sedentary $(\mathrm{db} / \mathrm{db}$ sedentary) or an exercise-trained ( $\mathrm{db} / \mathrm{db}$-exercise) group. ET was performed using an electrically driven treadmill (Exer-3/6 treadmill, Columbus Intr., $\mathrm{OH}$ ) 5 days per week based on a graded increase in duration and intensity, as previously described. ${ }^{26}$ Week 1 consisted of running for $10 \mathrm{mins}$ at $10 \mathrm{~m} / \mathrm{min}$, followed by $20 \mathrm{~min}$ at $10 \mathrm{~m} / \mathrm{min}$ for week 2 , and $30 \mathrm{mins}$ at $12 \mathrm{~m} /$ min for week 3 . For weeks 4 to 8 , mice rat for $30 \mathrm{mins}$ at $15 \mathrm{~m} / \mathrm{min}$. This treadmill belt speed corresponds to an estimated oxygen consumption of $\sim 50 \mathrm{~mL} / \mathrm{kg} / \mathrm{min}$. 30 Throughout the training period, the incline of the treadmill was kept at $0^{\circ}$. Mice were provided with regular chow (Teklad, Harlan Laboratories, Madison, WI, USA) and water ad libidum and housed under a standard alternating 12 -hr light/dark cycle at $22^{\circ} \mathrm{C}$.

\section{Blood and tissue sampling}

Blood was collected from overnight-fasted mice $48 \mathrm{hrs}$ after the last exercise session to eliminate any potential effects on insulin sensitivity. ${ }^{31}$ Between 8 and 11 am, nonanesthetized mice were placed on a warm heating pad for 30 mins to facilitate collection of blood by puncture of the submandibular vein. Blood was collected and centrifuged at 3,000 rpm for $5 \mathrm{mins}$ at $4^{\circ} \mathrm{C}$. The plasma was stored at $-80^{\circ} \mathrm{C}$ for assay of glucose using a colorimetric assay kit (Wako Chemicals USA, Richmond, VA, USA) and inflammatory markers (IL-6, CRP) using Elisa techniques according to manufacturer specifications (Alpco; Research and Clinical Immunoassays, Salem, NH, USA). The remaining 
erythrocytes were stored at $4^{\circ} \mathrm{C}$ for the determination of glycated hemoglobin content (Helena Laboratories, Beaumont, TX, USA). Mice were quickly euthanized by cervical dislocation. Hearts were removed and frozen with clamps precooled to the temperature of liquid $\mathrm{N}_{2}$ for analysis of genes and proteins of interest.

\section{Real-time PCR}

RNA for VEGF-A, hypoxia-inducible factor-alpha (HIF-1 $\alpha$ ), IL-1 $\beta$, and IL-6 was extracted with Trizol reagent (Invitrogen Life Technologies, Burlington, ON, USA) as reported ealier. ${ }^{25}$ Samples were incubated with deoxyribonuclease I (Invitrogen Life Technologies) at $37{ }^{\circ} \mathrm{C}$ for 30 mins to remove genomic DNA. PCR was performed in duplicate or triplicate using the iCycler IQ real-time PCR detection system (Bio-Rad Laboratories, Hercules, CA, USA) and SYBR ${ }^{\circledR}$ green chemistry (Bio-Rad Laboratories). Diluted cDNA was added to a reaction mixture (Green Supermix with $200 \mathrm{nM}$ forward and reverse primers) for amplification. Thermal cycling was set at $95^{\circ} \mathrm{C}$ for 2 mins, 40 cycles at $95^{\circ} \mathrm{C}$ for $30 \mathrm{~s}, 60^{\circ} \mathrm{C}$ for $30 \mathrm{~s}$, and $72^{\circ} \mathrm{C}$ for $30 \mathrm{~s}$. The primers were purchased from Invitrogen Life Technologies. Primer sets served to generate amplicons (Table 1). Following PCR, reaction products were melted $\left(1 \mathrm{~min}\right.$ at $95^{\circ} \mathrm{C}, 55^{\circ} \mathrm{C}$ with gradual $1.0^{\circ} \mathrm{C}$ increments to $95^{\circ} \mathrm{C}$ ). Optical data were collected over the duration of the temperature increments. The relative expression of RT-PCR products was determined by the $\Delta \Delta \mathrm{Ct}$ method. ${ }^{25} \mathrm{GAPDH}$ was selected as internal control because this gene shows consistent expression relative to other housekeeping genes among the groups in our experiments.

\section{Western blot analysis}

Heart samples were homogenized in modified RIPA buffer as previously reported. ${ }^{25}$ Samples were centrifuged $(10,000$ $g$ for $20 \mathrm{mins}, 4^{\circ} \mathrm{C}$ ), and protein concentration was measured in the supernatant using a modified Bradford assay. Protein
$(30 \mu \mathrm{g})$ was applied to each well and electrophoresed ( $2 \mathrm{hr}$ at $130 \mathrm{~V}$; MHC: $20 \mathrm{hr}$ at $140 \mathrm{v}$ ) with molecular weight markers (RPN800, Amersham Biosciences, Waltham, MA, USA). The protein bands were transferred onto polyvinylidene fluoride membranes (Hybond-C; Amersham Pharmacia, Piscataway, NJ, USA) at $20 \mathrm{~V}$ for 60 mins at room temperature using a transfer buffer. The blots were blocked with blocking buffer (5\% nonfat milk in $10 \mathrm{mmol} / \mathrm{L}$ Tris $\mathrm{pH} 7.5$, $100 \mathrm{mmol} / \mathrm{L} \mathrm{NaCl}, 0.1 \%$ Tween 20). Membranes were probed with specific primary antibodies (endothelial nitric oxide synthase [eNOS], 1:1000, Santa Cruz Biotechnology, Dallas, TX, USA; GLUT4, 1: 10,000, Bio-Rad Laboratories, Inc; TNF- $\alpha, 1: 2000$, Cell Signaling, Beverly, MA, USA). Blots were reprobed with an anti- $\beta$-GAPDH antibody (1:20,000; Sigma-Aldrich, St. Louis, MO, USA), washed using tris-buffered saline washing buffer $(10 \mathrm{mmol} / \mathrm{L}$ Tris $\mathrm{pH} 7.5,100 \mathrm{mmol} / \mathrm{L} \mathrm{NaCl}, 0.1 \%$ Tween 20 ), and then incubated with horseradish peroxidase-conjugated immunoglobulin G. Blots were detected by chemiluminescence detection system (RPN2132, Amersham) and visualized by exposure to Kodak X-Omat film. Densitometry measurements were performed using Photoshop 7 software.

\section{Statistical analysis}

Statistical analysis was performed using the statistical software package Prism 3.0. ANOVA followed by the TukeyKramer post hoc test was applied to analyze differences in groups tested. All values are expressed as mean \pm SEM.

\section{Results}

Physical characteristics, plasma levels of glucose, and inflammatory cytokines, after 8 weeks of ET, are presented in Table 2. As expected, body weight was significantly higher in diabetic mice compared with lean control mice, confirming the obese state associated with the $\mathrm{db} / \mathrm{db}$ model. However, ET did not significantly improve the obesity associated with these mice.

Table I PCR primer sequences

\begin{tabular}{|c|c|c|c|}
\hline Gene & Sense primer $\left(5^{\prime}-3^{\prime}\right)$ & Antisense primer $\left(5^{\prime}-3^{\prime}\right)$ & Accession no. \\
\hline VEGF & CACCCACGACAGAAGG & TCACAGTGAACGCTCCC & NM_00I025250 \\
\hline HIF-I & AGTCGGACAGCCTCA & TGCTGCCTTGTATGGGA & NM_0I043I \\
\hline IL-I $\beta$ & TCCCCAGCCCTTTTGTTGA & TTAGAACCAAATGTGGCCGTG & NM_00836I \\
\hline IL-6 & TCTCCACAAGCGCCTTCG & CTCAGGGCTGAGATGCCG & NM_03II68 \\
\hline Actin & ACCAACTGGGACGATATGGAGAAGA & TACGACCAGAGGCATACAGGGACAA & NM_007393 \\
\hline GAPDH & TTCACCACCATGGAGAAGGC & GGCATGGACTGTGGTCATGA & NM_008084 \\
\hline
\end{tabular}

Abbreviations: VEGF, vascular endothelial growth factor; HIF-I $\alpha$, hypoxia-inducible factor alpha; IL-I $\beta$, interleukin I beta; GAPDH, glyceraldehyde-3-phosphate dehydrogenase. 
Table 2 The effects of exercise training on selected physical characteristics of $\mathrm{db} / \mathrm{db}$ mice

\begin{tabular}{|l|l|l|l|}
\hline Parameter & $\begin{array}{l}\text { db/ } \\
\text { +Control }\end{array}$ & $\begin{array}{l}\text { db/db } \\
\text { Sedentary }\end{array}$ & $\begin{array}{l}\text { db/db } \\
\text { Exercise }\end{array}$ \\
\hline Body weight (g) & $25.8 \pm 0.5$ & $42.3 \pm 1 . I^{*}$ & $39.5 \pm 1.4^{*}$ \\
Heart weight (mg) & $114 \pm 5$ & $104 \pm 2$ & $98 \pm 2^{*}$ \\
HW/BW $\left(\times 10^{3}\right)$ & $4.43 \pm 0.21$ & $2.46 \pm 0.04^{*}$ & $2.49 \pm 0.13^{*}$ \\
Plasma glucose (mg/dL) & $175 \pm 13$ & $478 \pm 1 I^{*}$ & $483 \pm 8^{*}$ \\
Total GHb (\%) & $5.6 \pm 0.1$ & $10.7 \pm 0.2^{*}$ & $11.8 \pm 0.4^{*}+$ \\
Hb $b_{\text {lac }}(\%)$ & $4.8 \pm 0.1$ & $8.3 \pm 0.2^{*}$ & $9.0 \pm 0.3^{*}+$ \\
Plasma CRP (ng/ml) & $15.21 \pm 0.8 \mathrm{I}$ & $18.22 \pm 0.78 \ddagger$ & $18.16 \pm 1.16$ \\
Plasma IL-6 (pg/ml) & $1.47 \pm 0.70$ & $3.33 \pm 0.59$ & $4.37 \pm 1.70$ \\
\hline
\end{tabular}

Notes: Values are reported as mean \pm SEM for 7-9 mice in each group. $* P<0.05$ compared to lean mice; $\uparrow P<0.05$ compared to $\mathrm{db} / \mathrm{db}$ sedentary; $\ddagger p=0.050 \mathrm{I}$ compared to lean mice.

Abbreviations: $\mathrm{Hb}$, hemoglobin; $\mathrm{HW}$, heart weight; BW body weight; $\mathrm{GHb}$, glycated hemoglobin. CRP, C-reactive peptide; IL-6, interleukin-6.

Plasma glucose levels were significantly elevated in diabetic mice compared to lean control mice. Following 8 weeks of $\mathrm{ET}, \mathrm{db} / \mathrm{db}$ mice remained hyperglycemic and total glycated hemoglobin and hemoglobin $1_{\mathrm{ac}}$ levels were significantly higher compared to sedentary diabetic mice. These results suggest that glycemic control further deteriorated as a result of ET.

Plasma levels of IL-6 were higher by $\sim 56 \%$ in $\mathrm{db} / \mathrm{db}$ mice, although this did not reach statistical significance. Plasma IL-6 levels were not affected by ET, but tended to be higher in $\mathrm{db} / \mathrm{db}$ mice after ET compared to sedentary $\mathrm{db} / \mathrm{db}$ mice. Plasma CRP levels were significantly higher $(P<0.0501)$ in $\mathrm{db} / \mathrm{db}$ mice compared to control mice and were not affected by ET in $\mathrm{db} / \mathrm{db}$ mouse.

Expression of eNOS in hearts of $\mathrm{db} / \mathrm{db}$ hearts following ET is illustrated in Figure 1. A significant reduction in the expression of eNOS was observed in sedentary $\mathrm{db} / \mathrm{db}$ hearts compared to control hearts. Although ET resulted in a significant increase in the expression of eNOS compared to sedentary $\mathrm{db} /$ $\mathrm{db}$ mice, expression of this endothelial marker remained lower compared to hearts from lean control mice.

Figure 2 illustrates the effects of ET on mRNA expression of VEGF-A and HIF-1 $\alpha$. Expression of VEGF-A and HIF- $\alpha$ were not altered by the diabetic state. However, increases of nearly $40-45 \%$ for both markers of angiogenesis were observed in $\mathrm{db} / \mathrm{db}$ hearts after ET. However, when comparing the expression of VEGF-A and HIF- $1 \alpha$ between lean control and ET-hearts, significant differences were observed.

Expression of TNF- $\alpha$ and GLUT4 was measured to determine whether they are reciprocally related. As illustrated in Figure 3, cardiac TNF- $\alpha$ was significantly

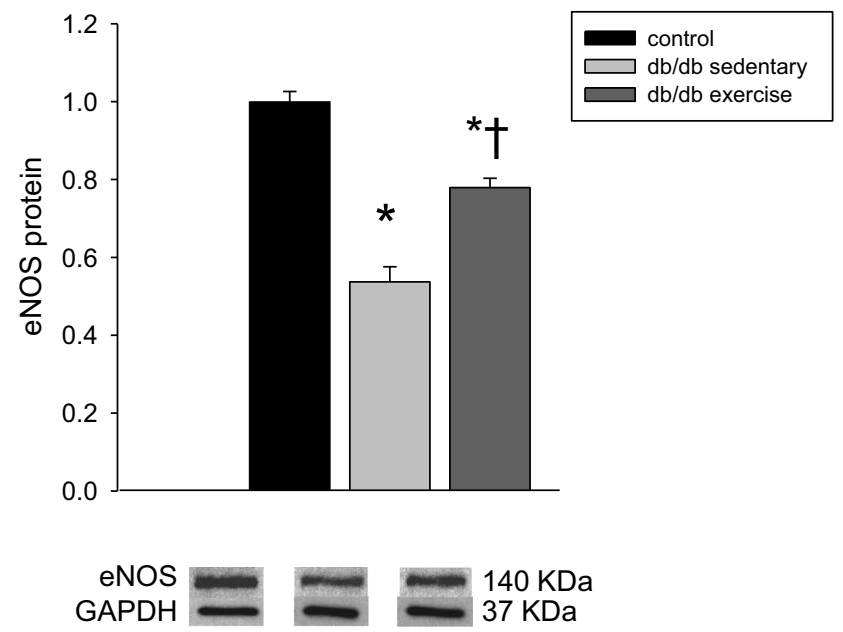

Figure I The effects of diabetes and exercise training on cardiac eNOS protein expression. Values are reported as mean \pm SEM for 4-6 mice per group. ${ }^{*} P<0.05$, compared to lean control mice. $+P<0.05$ compared to $\mathrm{db} / \mathrm{db}$ sedentary mice. Abbreviations: eNOS, endothelial nitric oxide synthane; GAPDH, glyceraldehyde-3- phosphate dehydrogenase.

increased in sedentary $\mathrm{db} / \mathrm{db}$ mice compared with control mice. ET resulted in a significant decrease in the expression of TNF- $\alpha$. However, decreased expression of TNF- $\alpha$ was not associated with increased GLUT4 content from whole heart homogenates after ET. Gene and protein expressions of GLUT1 were also not affected by the diabetic state or ET (data not provided).

The effects of diabetes and ET on mRNA expression of IL- 6 and IL-1 $\beta$ are illustrated in Figure 4. Expression of IL-was was significantly increased in hearts from sedentary $\mathrm{db} / \mathrm{db}$ mice compared with control mice. A significant reduction in the expression of IL- 6 was observed in $\mathrm{db} / \mathrm{db}$ hearts after ET. There were no differences in IL-1 $\beta$ between control and sedentary $\mathrm{db} / \mathrm{db}$ hearts. However, IL-1 $\beta$ expression was significantly decreased in $\mathrm{db} / \mathrm{db}$ hearts after ET.

\section{Discussion}

Regular physical activity is a healthy and effective nonpharmacological approach for the management of T2DM. Exercise helps achieve better glucose control, decreases body weight, and improves cardiovascular health. In this study, we used the $\mathrm{db} / \mathrm{db}$ mouse because of its close similarity to the human condition of T2DM. The onset of diabetes in this model is gradual and is characterized by obesity, insulin resistance, hyperglycemia, systemic inflammation, and cardiac dysfunction. The results of our study indicate that ET for a period of 8 weeks provided cardioprotection in the form of decreased expression of 

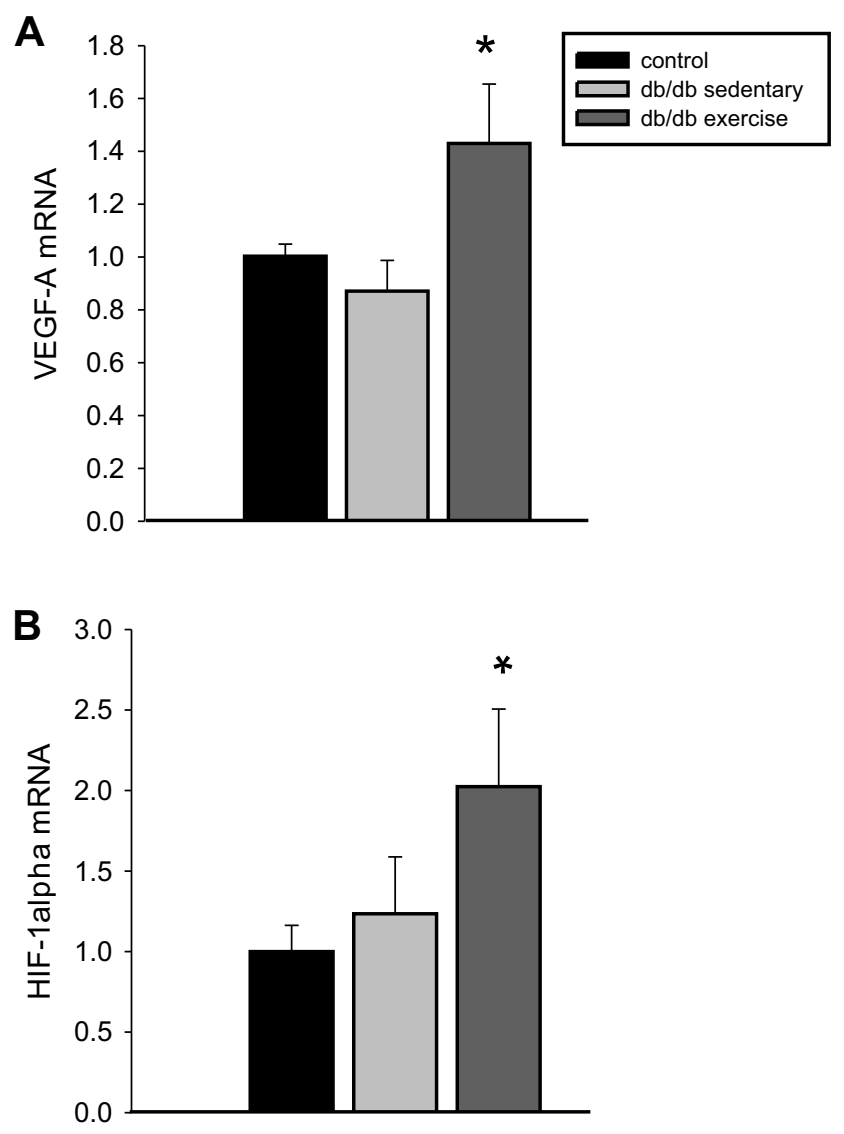

Figure 2 The effects of diabetes and exercise training on cardiac mRNA VEGF-A (panel A) and HIF-l $\boldsymbol{\alpha}$ (panel B) expression. Values are reported as mean $\pm \mathrm{SEM}$ for 4-6 mice per group. ${ }^{*} P<0.05$ compared to lean control mice.

Abbreviations: VEGF-A, vascular endothelial growth factor; HIF-I $\alpha$, hypoxiainduced factor

genes associated with insulin resistance and endothelial dysfunction and improved gene expression of markers relating to angiogenesis in $\mathrm{db} / \mathrm{db}$ heart. These benefits afforded by ET occurred independently of glucose control, systemic inflammation, and obesity.

The observation that $\mathrm{db} / \mathrm{db}$ mice remained obese after ET is consistent with earlier studies. ${ }^{22,26-28}$ The reasons for this effect are not known, although it has been suggested that treadmill running may worsen the diabetic state by increasing the levels of stress hormones. By its nature, chronic treadmill running is considered a form of forced exercise known to elicit an exaggerated cortisol response in the $\mathrm{db} / \mathrm{db}$ mouse, ${ }^{24-28,32}$ which is a well-established risk factor contributing to visceral obesity and weight gain in diabetes and obesity, ${ }^{33,34}$ On the other hand, low-intensity voluntary running designed to mimic exercise programs for patients with chronic disorders proves to be more efficient in preventing weight gain and decreasing food
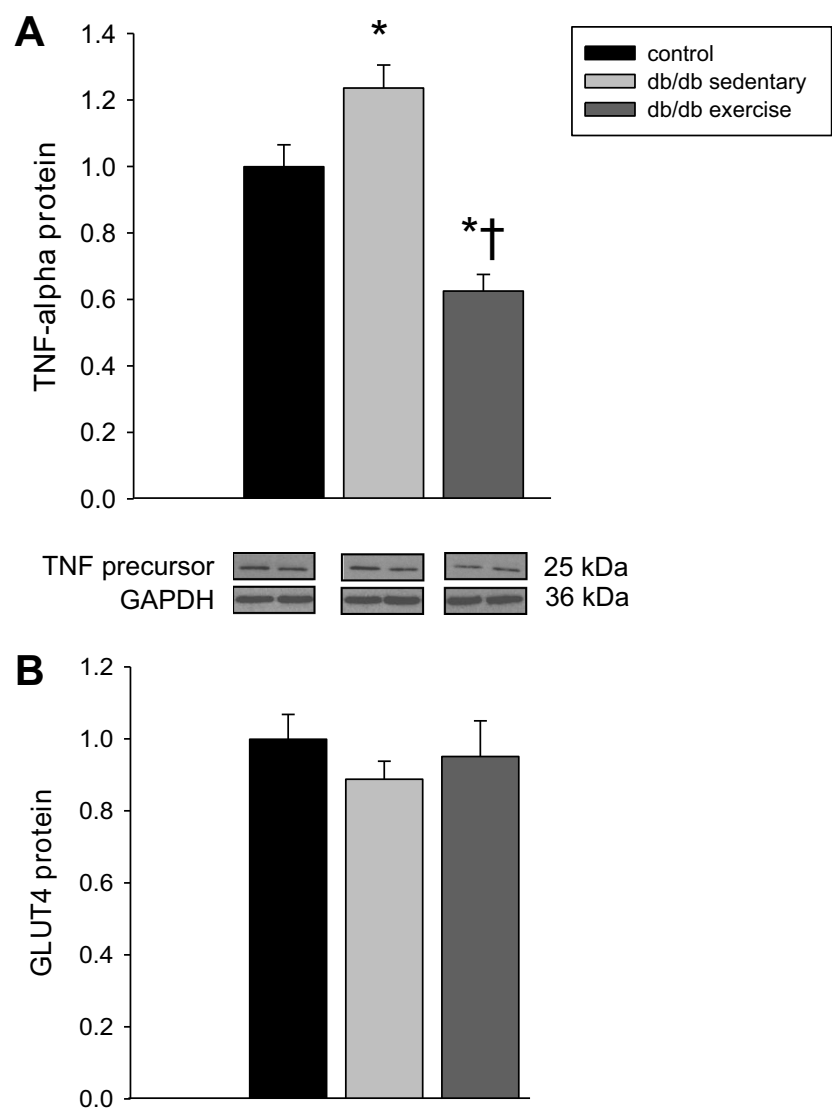

Figure 3 The effects of diabetes and exercise training on cardiac TNF- $\alpha$ (panel A) and GLUT4 (panel B) protein expression. Values are reported as mean \pm SEM for 4-6 mice per group. $* P<0.05$ compared to lean control mice. $\uparrow P<0.05$ compared to $\mathrm{db} / \mathrm{db}$ sedentary mice.

Abbreviations: TNF- $\alpha$, tumor necrosis factor-alpha; GLUT4, glucose transporter protein 4; GAPDH, glyceraldehyde-3-phosphate dehydrogenase.

intake and urinary corticosterone excretion in the $\mathrm{db} / \mathrm{db}$ mouse. $^{27,28}$

The effects of ET on glucose regulation have been studied in the $\mathrm{db} / \mathrm{db}$ mouse. Most of these studies showed that the $\mathrm{db} / \mathrm{db}$ mouse remained either hyperglycemic or demonstrated only slight improvements in blood glucose levels after ET. ${ }^{8,22-28}$ Following 8 weeks of ET, db/db mice were hyperglycemic and glycated hemoglobin $1_{\mathrm{ac}}$ levels remained elevated compared to their sedentary diabetic counterparts, indicating that glycemic control further deteriorated from ET. Similar results have been reported after 5 and 12 weeks of treadmill running at the same intensity in the leptin-deficient ob/ob mouse model of severe obesity. ${ }^{27,28,35}$ Evidence suggests that these maladaptations to exercise are attributed to an increase in insulin resistance from defective glucose transport and insulin signaling in skeletal muscle. ${ }^{27}$ Moreover, the $\mathrm{db} /$ $\mathrm{db}$ mouse exhibits hypercorticosteronism and increased expression of $11 \beta$-hydroxysteroid dehydrogenase type 1 , 

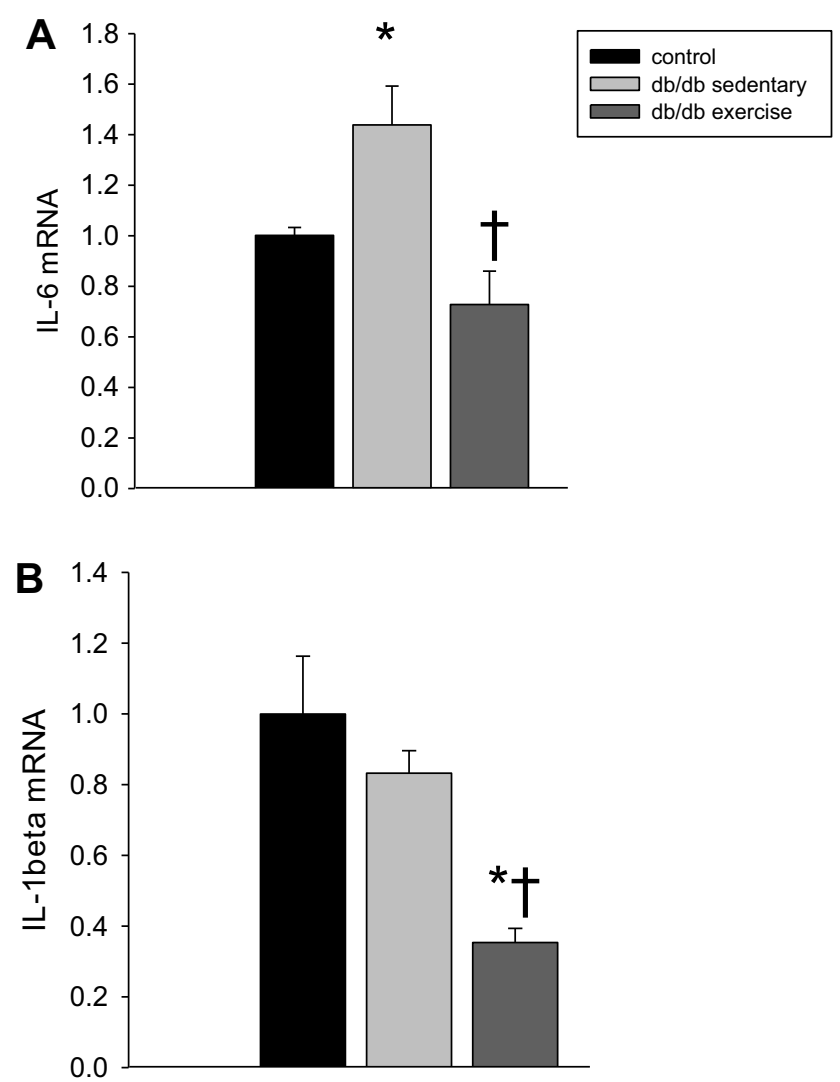

Figure 4 The effects of diabetes and exercise training on cardiac mRNA IL-6 (panel A) and IL- I $\boldsymbol{\beta}$ (panel B) expression. Values are reported as mean \pm SEM for 4-6 mice per group. ${ }^{*} P<0.05$ compared to lean control mice. $\nmid P<0.05$ compared to $\mathrm{db} / \mathrm{db}$ sedentary mice.

Abbreviation: IL-I $\beta$, interleukin-I beta.

both contributing to elevated rates of hepatic glucose production. ${ }^{24,32}$ Acute exercise and chronic ET further increase endogenous glucocorticoid secretion in the $\mathrm{db} /$ $\mathrm{db}$ mouse, resulting in increased rates of hepatic gluconeogenesis and hyperglycemia. ${ }^{24,28}$ This is in sharp contrast to earlier studies in the obese Zucker and Zucker diabetic fatty rat where the hypercorticosteronism and insulin resistance were prevented and an improvement in hepatic glucose production rates and hyperglycemia was observed in response to treadmill running. ${ }^{36,37}$ The reasons for these discrepancies are not known, but may relate to differences in the severity of diabetes and adiposity exhibited by the rodents used. Leptin resistance in the $\mathrm{db} / \mathrm{db}$ mouse may also explain the hyperglycemia since treatment of uncontrolled hypoleptinemic type 1 diabetic rats with leptin normalizes plasma glucose and hepatic glucose production and improves energy expenditure and running activity in obese mice. ${ }^{38,39}$

T2DM is a low-grade inflammatory disease, and patients often have elevated plasma levels of the proinflammatory cytokines CRP and IL- $6 .{ }^{17} \mathrm{CRP}$ is also predictor of diabetes, and levels of CRP in plasma are correlated with insulin resistance, obesity, ${ }^{40}$ glycated hemoglobin, ${ }^{41}$ and endothelial dysfunction. ${ }^{42}$ Further, synthesis of hepatic CRP is mediated by IL-6 and CRP production is induced by hyperglycemia. ${ }^{43,44}$ Our results indicate that after moderate ET circulating levels of proinflammatory cytokines remained elevated in $\mathrm{db} / \mathrm{db}$ mice. These findings are in keeping with recent work in $\mathrm{db} / \mathrm{db}$ mice where a persistent inflammation was observed after 6 weeks of forced wheel ET, although endothelial function was observed in these mice. ${ }^{23}$ It is well established that elevated CRP levels and hyperglycemia inhibit vascular function by decreasing protein expression eNOS. ${ }^{45-47}$ Declining levels of eNOS and decreased action of NO are central to the pathogenesis and clinical course of cardiovascular dysfunction. eNOS is also a component of the cardioprotective oxytocin-atrial natriuretic peptide system, ${ }^{48}$ which is downregulated in diabetes and linked to cardiomyopathy observed in these mice. ${ }^{49-51}$ Our results indicate that the expression of eNOS was significantly increased in diabetic hearts after ET. This is consistent with earlier studies using this mouse model of diabetes and also shows that ET is beneficial on eNOS expression even in the presence of severe hyperglycemia and obesity. ${ }^{25,26}$ Although this would suggest improved endothelial function, ${ }^{52}$ the functional consequences of this increase in eNOS in response to ET were not determined in this study. However, previous studies have reported improved endothelial function, expressed as vasodilation to acetylcholine in aortae and coronary arteries, in the $\mathrm{db} / \mathrm{db}$ mouse trained under similar exercise conditions. $^{8,22,23}$

In addition to its role in vascular function, eNOS is a key modulator of angiogenesis in heart. ${ }^{53,54}$ Angiogenesis is stimulated as a compensatory response to ischemia and ET in the aging heart. ${ }^{55}$ Further, evidence indicates that hyperglycemia inhibits angiogenesis in hearts of diabetic patients. ${ }^{56}$ Recent studies demonstrated that ET in the form of wheel or treadmill running increased VEGF-A levels in hearts from STZ-induced type 1 insulinotropic diabetes rats. ${ }^{12}$ This effect may explain, in part, the benefits of regular exercise on cardiovascular disease risk and coronary blood in diabetes. Coronary blood is improved with training because of angiogenesis and increased endothelial vasodilation function. ${ }^{57}$ Taken together, our results show that the increase in mRNA expression of VEGF-A expression is 
consistent with the changes in eNOS and occur independently of hyperglycemia. In addition to the metabolic abnormalities in substrate utilization, inflammation, and disturbances in cardiac function, hearts from diabetic models also display impaired responses to hypoxia. ${ }^{58}$ Hypoxia protects the myocardium from lethal hypoxic and ischemic conditions by activating HIF-1 $\alpha$, a key transcription factor involved in the expression of VEGF. ${ }^{59}$ We measured mRNA expression of HIF-1 $\alpha$ to determine whether this was associated with VEGF-A expression observed in $\mathrm{db} /$ $\mathrm{db}$ hearts after ET. When compared to lean control mice, the increased expression of HIF-1 $\alpha$ observed in $\mathrm{db} / \mathrm{db}$ hearts after ET could explain the training effect on VEGF-A expression.

Increased inflammation in $\mathrm{T} 2 \mathrm{DM}$ is known to contribute to disturbances in endothelial function, glucose metabolism, and cardiac function. ${ }^{17-61}$ TNF- $\alpha$ and IL-6 levels are increased in the endothelial vasculature of hearts of diabetic mice and have been identified as key mediators precipitating vascular dysfunction. Expression of TNF- $\alpha$ and IL- 6 was increased in hearts of sedentary $\mathrm{db} / \mathrm{db}$ mice and ET significantly decreased expression of these cytokines. Decreased TNF- $\alpha$ expression has been previously reported in $\mathrm{db} / \mathrm{db}$ mice after 10 weeks of $\mathrm{ET}$, and this was associated with improved vasodilatory function of coronary arteries and a $20-25 \%$ decrease in serum IL- $6,{ }^{61}$ suggesting that ET is protective and inhibits the progression of vascular dysfunction. ${ }^{62}$ Moreover, studies indicate that TNF- $\alpha$ also regulates peripheral glucose metabolism. Evidence for this role is supported in mice lacking TNF- $\alpha$ function, demonstrating improved insulin sensitivity following high-fat feeding, and similarly, in which an intravenous infusion of TNF- $\alpha$ inhibits insulin-mediated glucose uptake in healthy subjects. ${ }^{63,64}$ However, in cardiac tissue of exercise-trained $\mathrm{db} / \mathrm{db}$ mice, decreased TNF- $\alpha$ content was not accompanied with reciprocal changes in the expression of either GLUT4 protein content or GLUT1 gene and protein expression of (data not provided). However, one might expect that the reduction in these cytokines after ET can potentially lead to an improvement in vascular function and glucose metabolism, and that the changes in gene and protein expression induced from ET may appear to counter the diabetic state. Admittedly, as a limitation of this study, the effects of ET on these proinflammatory cytokines on vascular function and peripheral glucose metabolism in this study must be considered.

\section{Conclusion}

In this study, we show that 8 weeks of moderate-intensity ET does not improve glucose control and plasma levels of inflammatory cytokines, but is associated with increased expression of key angiogenic markers, possibly by enhancing NO availability in hearts of diabetic mice. On the other hand, expression of key cytokines involved in the progression of endothelial dysfunction and insulin resistance in cardiac muscle was reduced in response to ET. The observation that these beneficial effects of ET occurred independent of obesity, hyperglycemia, and the inflammatory state suggests that ET is protective in nature.

\section{Acknowledgments}

The study was funded a grant from the Midwestern University Office of Research and Sponsored Programs (TLB).

\section{Disclosure}

The authors report no conflict of interest in the work.

\section{References}

1. Booth FW, Roberts CK, Laye MJ. Lack of exercise is a major cause of chronic diseases. Compr Physiol. 2012;2(2):1143-1211. doi:10.1002/cphy.c110025

2. Booth FW, Roberts CK, Thyfault JP, et al. Role of inactivity in chronic diseases: evolutionary insight and pathophysiological mechanisms. Physiol Rev. 2017;97(4):1351-1402. doi:10.1152/ physrev.00019.2016

3. Kannel WB, McGee DL. Diabetes and cardiovascular disease. The Framingham study. JAMA. 1979;241(19):2035-2038.

4. Tuomilehto J, Lindstrom J, Eriksson JG, et al. Prevention of type 2 diabetes mellitus by changes in lifestyle among subjects with impaired glucose tolerance. $N$ Engl J Med. 2001;344:1343-1350. doi:10.1056/NEJM200105033441801

5. Després JP. Physical activity, sedentary behaviours, and cardiovascular health: when will cardiorespiratory fitness become a vital sign? Can J Cardiol. 2016;32(4):505-513. doi:10.1016/j.cjca.2015.12.006

6. Boule NG, Haddad E, Kenny GP, et al. Effects of exercise on glycemic control and body mass in type 2 diabetes mellitus: a meta-analysis of controlled clinical trials. JAMA. 2011;286:1218-1227. doi:10.1001/ jama.286.10.1218

7. Diabetes Prevention Program Research Group. Reduction of the incidence of type 2 diabetes with lifestyle intervention or metformin. $N$ Engl J Med. 2002;346:393-403. doi:10.1056/NEJMoa012512

8. Moien-Afshari F, Khazaei M, Ghosh S, et al. Exercise restores coronary vascular function independent of myogenic tone or hyperglycemic status in $\mathrm{db} / \mathrm{db}$ mice. Am J Physiol Heart Circ Physiol. 2008;295:H1470-H1480. doi:10.1152/ajpheart.00016.2008

9. Ghosh S, Khazaei M, Moien-Afshari F, et al. Moderate exercise attenuates caspase- 3 activity, oxidative stress, and inhibits progression of diabetic renal disease in $\mathrm{db} / \mathrm{db}$ mice. Am J Physiol Renal Physiol. 2009;296(4):F700-F708. doi:10.1152/ajprenal.90548.2008

10. Esser KA, Su W, Matveev S, et al. Voluntary wheel running ameliorates vascular smooth muscle hyper-contractility in type 2 diabetic $\mathrm{db} / \mathrm{db}$ mice. Appl Physiol Nutr Metab. 2007;32:711-720. doi:10.1139/H07-058 
11. Prior BM, Yang HT, Terjung RL. What makes vessels grow with exercise training? J Appl Physiol. 2004;97(3):1119-1128. doi:10.1152/ japplphysiol.00035.2004

12. Erekat NS, Al-Jarrah MD, Al Khatib AJ. Treadmill exercise training improves vascular endothelial growth factor expression in the cardiac muscle of type I diabetic rats. Cardiol Res. 2014;5(1):23-29. doi:10.14740/cr314w

13. Chodari L, Mohammadi M, Ghorbanzadeh V, Dariushnejad H, Mohaddes G. Testosterone and voluntary exercise promote angiogenesis in hearts of rats with diabetes by enhancing expression of VEGF-A and SDF-1a. Can J Diabetes. 2016;40(5):436-441. doi:10.1016/j.jcjd.2016.03.004

14. Ghorbanzadeh V, Mohammadi M, Dariushnejad H, et al. Effects of crocin and voluntary exercise, alone or combined, on heart VEGF-A and HOMA-IR of HFD/STZ induced type 2 diabetic rats. $J$ Endocrinol Invest. 2016;39(10):1179-1186. doi:10.1007/s40618016-0456-2

15. Kivelä R, Silvennoinen M, Touvra AM, et al. Effects of experimental type 1 diabetes and exercise training on angiogenic gene expression and capillarization in skeletal muscle. FASEB J. 2006;20 (9):1570-1582. doi:10.1096/fj.05-4780fje

16. Gielen S, Adams V, Möbius-Winkler S, et al. Anti-inflammatory effects of exercise training in the skeletal muscle of patients with chronic heart failure. J Am Coll Cardiol. 2003;42(5):861-868.

17. Donath MY, Shoelson SE. Type 2 diabetes as an inflammatory disease. Nat Rev Immunol. 2011;11(2):98-107. doi:10.1038/nri2925

18. Dick SA, Epelman S. Chronic heart failure and inflammation: what do we really know? Circ Res. 2016;119(1):159-176. doi:10.1161/ CIRCRESAHA.116.308030

19. Caballero AE. Endothelial dysfunction in obesity and insulin resistance: a road to diabetes and heart disease. Obes Res. 2003;11 (11):1278-1289. doi:10.1038/oby.2003.174

20. Zhang H, Park Y, Wu J, et al. Role of TNF-alpha in vascular dysfunction. Clin Sci (Lond). 2009;116(3):219-230. doi:10.1042/ CS20080196

21. Zhang H, Zhang C. Regulation of microvascular function by adipose tissue in obesity and type 2 diabetes: evidence of an adipose-vascular loop. Am J Biomed Sci. 2009;1(2):133. doi:10.5099/aj090200133

22. Moien-Afshari F, Ghosh S, Elmi S, et al. Exercise restores endothelial function independently of weight loss or hyperglycaemic status in $\mathrm{db} / \mathrm{db}$ mice. Diabetologia. 2008;51(7):1327-1337. doi:10.1007/ s00125-008-0996-x

23. Sallam N, Khazaei M, Laher I. Effect of moderate-intensity exercise on plasma C-reactive protein and aortic endothelial function in type 2 diabetic mice. Mediators Inflamm. 2010;2010:149678. doi:10.1155/ 2010/149678

24. Brust KB, Corbell KA, Al-Nakkash L, et al. Expression of gluconeogenic enzymes and 11 $\beta$-hydroxysteroid dehydrogenase type 1 in liver of diabetic mice after acute exercise. Diabetes Metab Syndr Obes. 2014;7:495-504. doi:10.2147/DMSO.S70767

25. Broderick TL, Jankowski M, Gutkowska J. The effects of exercise training and caloric restriction on the cardiac oxytocin natriuretic peptide system in the diabetic mouse. Diabetes Metab Syndr Obes. 2017;10:27-36. doi:10.2147/DMSO.S115453

26. Gutkowska J, Broderick TL, Bogdan D, et al. Downregulation of oxytocin and natriuretic peptides in diabetes: possible implications in cardiomyopathy. J Physiol. 2009;587:4725-4736. doi:10.1113/ jphysiol.2009.176461

27. Sennott J, Morrissey J, Standley PR, et al. Treadmill exercise training fails to restore defects in glucose, insulin and muscle glut 4 content in the $\mathrm{db} / \mathrm{db}$ mouse model of diabetes. Pathophysiology. 2008;15 (3):173-179. doi:10.1016/j.pathophys.2008.06.001

28. Parrott CR, Ghosh P, Tedeschi J, et al. Urinary corticosterone and normetanephrine levels after voluntary wheel and forced treadmill running in the $\mathrm{db} / \mathrm{db}$ mouse. Journal of Diabetes Mellitus. 2011;1:71-78. doi:10.4236/jdm.2011.14011
29. Leibel RL, Chung WK, Chua SC Jr. The molecular genetics of rodent single gene obesities. J Biol Chem. 1997;272(51):31937-31940.

30. Høydal MA, Wisløff U, Kemi OJ, Ellingsen O. Running speed and maximal oxygen uptake in rats and mice: practical implications for exercise training. Eur J Cardiovasc Prev Rehabil. 2007;14:753-760. doi:10.1097/HJR.0b013e3281 eacef1

31. James DE, Burleigh KM, Kraegen EW, et al. Effect of acute exercise and prolonged training on insulin response to intravenous glucose in vivo in rat. 1. J Appl Physiol. 1983;55:1660-1664. doi:10.1152/ jappl.1983.55.6.1660

32. Coleman DL, Burkart DL. Plasma corticosterone concentrations in diabetic (db) mice. Diabetologia. 1977;13(1):25-26. doi:10.1007/ BF00996323

33. Andrews RC, Walker BR. Glucocorticoids and insulin resistance: old hormones, new targets. Clin Sci (Lond). 1999;96(5):513-523.

34. Perelló M, Moreno G, Gaillard RC, Spinedi E. Glucocorticoiddependency of increased adiposity in a model of hypothalamic obesity. Neuro Endocrinol Lett. 2004;25(1-2):119-126.

35. Broderick TL, Wang D, Jankowski M, et al. Unexpected effects of voluntary exercise training on natriuretic peptide and receptor mRNA expression in the ob/ob mouse heart. Regul Pept. 2014;188:52-59. doi:10.1016/j.regpep.2013.12.005

36. Campbell JE, Király MA, Atkinson DJ, et al. Regular exercise prevents the development of hyperglucocorticoidemia via adaptations in the brain and adrenal glands in male Zucker diabetic fatty rats. Am $J$ Physiol Integr Comp Physiol. 2010;299(1):R168-R176. doi:10.1152/ajpregu.00155.2010

37. Chang SP, Chen YH, Chang WC, et al. Merit of physical exercise to reverse the higher gene expression of hepatic phosphoenolpyruvate carboxykinase in obese Zucker rats. Life Sci. 2006;79(3):240-246. doi:10.1016/j.lfs.2005.12.044

38. Perry RJ, Zhang XM, Zhang D, et al. Leptin reverses diabetes by suppression of the hypothalamic-pituitary-adrenal axis. Nat Med. 2014;20(7):759-763. doi:10.1038/nm.3579

39. Morton GJ, Kaiyala KJ, Fisher JD, et al. Identification of a physiological role for leptin in the regulation of ambulatory activity and wheel running in mice. Am J Physiol Endocrinol Metabol. 2011;300:E392-E401. doi:10.1152/ajpendo.00546.2010

40. Visser M, Bouter LM, McQuillan GM, et al. Elevated C-reactive protein levels in overweight and obese adults. JAMA. 1999;282 (22):2131-2135.

41. Gómez JM, Vila R, Catalina P, et al. The markers of inflammation and endothelial dysfunction in correlation with glycated haemoglobin are present in type 2 diabetes mellitus patients but not in their relatives. Glycoconj J. 2008;25(6):573-579. doi:10.1007/s10719-008-9118-8

42. Calles-Escandon J, Cipolla M. Diabetes and endothelial dysfunction: a clinical perspective. Endocr Rev. 2001;22(1):36-52. doi:10.1210/ edrv.22.1.0417

43. Fain JN, Madan AK, Hiler ML, et al. Comparison of the release of adipokines by adipose tissue, adipose tissue matrix, and adipocytes from visceral and subcutaneous abdominal adipose tissues of obese humans. Endocrinology. 2004;145(5):2273-2282. doi:10.1210/ en.2003-1336

44. You YK, Huang XR, Chen HY, et al. C-reactive protein promotes diabetic kidney disease in $\mathrm{db} / \mathrm{db}$ mice via the CD32b-Smad3-mTOR signaling pathway. Sci Rep. 2016;6:26740. doi:10.1038/srep26740

45. Verma S, Szmitko PE, Ridker PM. C-reactive protein comes of age. Nat Clin Pract Cardiovasc Med. 2005;2(1):29-36. doi:10.1038/ ncpcardio0074

46. Verma S, Kuliszewski MA, Li SH, et al. C-reactive protein attenuates endothelial progenitor cell survival, differentiation, and function: further evidence of a mechanistic link between C-reactive protein and cardiovascular disease. Circulation. 2004;109(17):2058-2067. doi:10.1161/01.CIR.0000127577.63323.24

47. Giacco F, Brownlee M. Oxidative stress and diabetic complications. Circ Res. 2010;107(9):1058-1070. doi:10.1161/CIRCRESAHA.110.223545 
48. Gutkowska J, Jankowski M, Mukaddam-Daher S, et al. Oxytocin is a cardiovascular hormone. Braz J Med Biol Res. 2000;33:625-633.

49. Bartells ED, Nielson JM, Bisgaard LS, et al. Decreased expression of natriuretic peptides associated with lipid accumulation in cardiac ventricle of obese mice. Endocrinology. 2010;151(11):5218-5225. doi:10.1210/en.2010-0355

50. BarouchLA, Berkowitz DE, Harrison RW, et al. Disruption of leptin signaling contributes to cardiac hypertrophy independently of body weight in mice. Circulation. 2003;108:754-759. doi:10.1161/01. CIR.0000083716.82622.FD

51. Plante E, Menaouar A, Danalache BA, et al. Oxytocin treatment prevents the cardiomyopathy observed in obese diabetic male $\mathrm{db} / \mathrm{db}$ mice. Endocrinology. 2015;156(4):1416-1428.

52. Förstermann U, Münzel T. Endothelial nitric oxide synthase in vascular disease: from marvel to menace. Circulation. 2006;113 (13):1708-1714. doi:10.1161/CIRCULATIONAHA.105.602532

53. Cooke JP, Losordo DW. Nitric oxide and angiogenesis. Circulation. 2002;105(18):2133-2135.

54. Lin KY, Ito A, Asagami T, et al. Impaired nitric oxide synthase pathway in diabetes mellitus: role of asymmetric dimethylarginine and dimethylarginine dimethylaminohydrolase. Circulation. 2002;106(8):987-992.

55. Iemitsu M, Maeda S, Jesmin S, et al. Exercise training improves aging-induced downregulation of VEGF angiogenic signaling cascade in hearts. Am J Physiol Heart Circ Physiol. 2006;291(3):H1290-H1298. doi:10.1152/ajpheart.00820.2005

56. KolluruGK, BirSC, KevilCG. Endothelial dysfunction and diabetes: effects on angiogenesis, vascular remodeling, and wound healing. Int J Vasc Med. 2012;2012:918267.
57. HambrechtR, Adams V, Erbs S, et al. Regular physical activity improves endothelial function in patients with coronary artery disease by increasing phosphorylation of endothelial nitric oxide synthase. Circulation. 2003;107(25):3152-3158. doi:10.1161/01. CIR.0000074229.93804.5C

58. Falcão-Pires I, Leite-Moreira AF. Diabetic cardiomyopathy: understanding the molecular and cellular basis to progress in diagnosis and treatment. Heart Fail Rev. 2012;17(3):325-344. doi:10.1007/s10741011-9257-z

59. Cerychova R, Pavlinkova G. HIF-1, metabolism, and diabetes in the embryonic and adult heart. Front Endocrinol (Lausanne). 2018;15 (9):460. doi:10.3389/fendo.2018.00460

60. McTiernan CF, Lemster BH, Frye C, et al. Interleukin-1 beta inhibits phospholamban gene expression in cultured cardiomyocytes. Circ Res. 1997;81(4):493-503.

61. Lee S, Park Y, Zhang C. Exercise training prevents coronary endothelial dysfunction in type 2 diabetic mice. Am J Biomed Sci. 2011;3 (4):241-252. doi:10.5099/aj110400241

62. Byrkjeland R, Njerve IU, Arnesen H, et al. Reduced endothelial activation after exercise is associated with improved $\mathrm{HbA}_{1 \mathrm{c}}$ in patients with type 2 diabetes and coronary artery disease. Diab Vasc Dis Res. 2017;14 (2):94-103. doi:10.1177/1479164116679077

63. Uysal KT, Wiesbrock SM, Marino MW, et al. Protection from obesity-induced insulin resistance in mice lacking TNF-alpha function. Nature. 1997;389(6651):610-614. doi:10.1038/39335

64. Plomgaard P, Bouzakri K, Krogh-Madsen R, et al. Tumor necrosis factor-alpha induces skeletal muscle insulin resistance in healthy human subjects via inhibition of Akt substrate 160 phosphorylation. Diabetes. 2005;54(10):2939-2945.

\section{Publish your work in this journal}

Diabetes, Metabolic Syndrome and Obesity: Targets and Therapy is an international, peer-reviewed open-access journal committed to the rapid publication of the latest laboratory and clinical findings in the fields of diabetes, metabolic syndrome and obesity research. Original research, review, case reports, hypothesis formation, expert opinion and commentaries are all considered for publication. The manuscript management system is completely online and includes a very quick and fair peer-review system, which is all easy to use. Visit http://www.dovepress.com/testimonials.php to read real quotes from published authors. 